\title{
Impacts of land cover and climate data selection on understanding terrestrial carbon dynamics and the $\mathrm{CO}_{2}$ airborne fraction
}

\author{
B. Poulter ${ }^{1,2}$, D. C. Frank ${ }^{3,4}$, E. L. Hodson ${ }^{1}$, and N. E. Zimmermann ${ }^{1}$ \\ ${ }^{1}$ Swiss Federal Research Institute WSL, Dynamic Macroecology, Zürcherstrasse 111, Birmensdorf 8903, Switzerland \\ ${ }^{2}$ Laboratoire des Sciences du Climat et de L'Environment, CEA, UVSQ, CNRS, Gif-sur Yvette, France \\ ${ }^{3}$ Swiss Federal Research Institute WSL, Dendroclimatology, Zürcherstrasse 111, Birmensdorf 8903, Switzerland \\ ${ }^{4}$ Oeschger Centre for Climate Change Research, University of Bern, 3012 Bern, Switzerland
}

Received: 11 February 2011 - Published in Biogeosciences Discuss.: 23 February 2011

Revised: 24 June 2011 - Accepted: 15 July 2011 - Published: 1 August 2011

\begin{abstract}
Terrestrial and oceanic carbon cycle processes remove $\sim 55 \%$ of global carbon emissions, with the remaining $45 \%$, known as the "airborne fraction", accumulating in the atmosphere. The long-term dynamics of the component fluxes contributing to the airborne fraction are challenging to interpret, but important for informing fossil-fuel emission targets and for monitoring the trends of biospheric carbon fluxes. Climate and land-cover forcing data for terrestrial ecosystem models are a largely unexplored source of uncertainty in terms of their contribution to understanding airborne fraction dynamics. Here we present results using a single dynamic global vegetation model forced by an ensemble experiment of climate (CRU, ERA-Interim, NCEP-DOE II), and diagnostic land-cover datasets (GLC2000, GlobCover, MODIS). For the averaging period 1996-2005, forcing uncertainties resulted in a large range of simulated global carbon fluxes, up to $13 \%$ for net primary production (52.4 to $60.2 \mathrm{Pg} \mathrm{C} \mathrm{a}^{-1}$ ) and $19 \%$ for soil respiration (44.2 to $54.8 \mathrm{Pg}$ $\mathrm{C} \mathrm{a}^{-1}$ ). The sensitivity of contemporary global terrestrial carbon fluxes to climate strongly depends on forcing data (1.2-5.9 $\mathrm{Pg} \mathrm{C} \mathrm{K}^{-1}$ or 0.5 to 2.7 ppmv $\mathrm{CO}_{2} \mathrm{~K}^{-1}$ ), but weakening carbon sinks in sub-tropical regions and strengthening carbon sinks in northern latitudes are found to be robust. The climate and land-cover combination that best correlate to the inferred carbon sink, and with the lowest residuals, is from observational data (CRU) rather than reanalysis climate data and with land-cover categories that have more stringent criteria for forest cover (MODIS). Since 1998, an increasing positive trend in residual error from bottom-up accounting of global sinks and sources (from 0.03 (1989-2005) to $0.23 \mathrm{Pg}$ $\mathrm{C} \mathrm{a}^{-1}$ (1998-2005)) suggests that either modeled drought sensitivity of carbon fluxes is too high, or that carbon emissions from net land-cover change is too large.
\end{abstract}

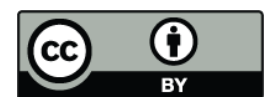

Correspondence to: B. Poulter (benjamin.poulter@1sce.ipsl.fr)

\section{Introduction}

Fossil fuel emission targets to limit global warming below a certain threshold are determined by the sensitivity of the climate system to greenhouse gas concentrations (Meinshausen et al., 2009). Nearly half the uncertainty in existing estimates for climate sensitivity stem from processes, rates and feedbacks of the global carbon cycle (Huntingford et al., 2009). Key questions include knowing the sensitivity of the carbon cycle to changes in climate (Frank et al., 2010) and how long the carbon cycle will act as a negative feedback to rising fossil fuel emissions (Friedlingstein et al., 2003).

Currently, about $55 \%$ of fossil fuel carbon emissions are removed from the atmosphere by a suite of terrestrial and oceanic processes with uptake rates governed by factors such as climate variability and changes in land cover (Le Quere et al., 2009). The remaining $\mathrm{CO}_{2}-$ the so called "airborne fraction" - is a key metric of both the anthropogenic contribution to global warming and a top-down estimate of all carbon-cycle processes.

Recent work has highlighted the challenge of monitoring and interpreting inter-annual variability of the airborne fraction. Direct analysis of the airborne fraction and its contemporary trend (1850-2007) suggests that any increase, representing weakening carbon sinks, is not statistically significant (Knorr, 2009). However, independent accounting of carbon sinks and fluxes from process-based ocean and dynamic global vegetation models suggest a possible weakening of biospheric carbon sinks (Le Quere et al., 2009). Accounting approaches are problematic, because they are unable to close the global carbon budget to less than a $2.1 \mathrm{Pg} \mathrm{C} \mathrm{a}^{-1}$ residual error, mostly due to uncertainty in modeling the terrestrial carbon cycle (Le Quere et al., 2009). In contrast, Sarmiento et al. (2010) assumed that the error from modeling terrestrial carbon fluxes could be reduced by using better constrained ocean and atmospheric measurements of $\mathrm{CO}_{2}$ to

Published by Copernicus Publications on behalf of the European Geosciences Union. 
Table 1. Spatial and temporal characteristics for the climate forcing data.

\begin{tabular}{llllll}
\hline Dataset & Type & Spatial resolution & Temporal resolution & Time period & Reference \\
\hline CRU TS 3.0 & Observations & 0.5 degrees & Monthly & $1901-2006$ & $\begin{array}{l}\text { Mitchell and Jones } \\
\text { (2005) }\end{array}$ \\
ERA-Interim & Reanalysis & 1.5 degrees (T255 gaussian grid) & 6-hourly & $1989-2010$ & $\begin{array}{l}\text { Berrisford et al. (2009); } \\
\text { Uppala et al. (2005) }\end{array}$ \\
NCEP-DOE II & Reanalysis & 1.5 degrees (T255 gaussian grid) & 6-hourly & $1979-2010$ & $\begin{array}{l}\text { Kalnay et al. (1996); } \\
\text { Kanamitsu et al. (2002) }\end{array}$ \\
\hline
\end{tabular}

infer terrestrial carbon dynamics. They concluded that the strength of the residual global terrestrial carbon sink may be increasing from a combination of a longer growing season in the Northern Hemisphere and $\mathrm{CO}_{2}$ fertilization. Clearly, improvements in terrestrial carbon-cycle model simulations, especially a rigorous quantification of associated uncertainties, are required to provide a more robust interpretation and quantification of the airborne fraction.

In addition to numerical descriptions of ecological processes (Ostle et al., 2009; Sitch et al., 2008) and model parameters (Zaehle et al., 2005), climate and land-cover forcing used in model simulations are a large source of uncertainty in dynamic global vegetation modeling (Hicke, 2005; Jung et al., 2007; Quaife et al., 2008; McGuire et al., 2001). Different methods used to create time series of gridded climate data from meteorological stations introduce uncertainty that propagates through ecosystem models (Zhao et al., 2006). And challenges in mapping and modeling land cover result in different estimates of productivity and respiration (Jung et al., 2007). While these uncertainties have been evaluated at continental scales, less is known about their effects globally. Here we systematically explore the choice of forcing data and how the resulting differences in model output (i) affects the interpretation of recent trends in the airborne fraction and (ii) contributes to residual error using standard source-sink accounting procedures (as in Le Quere et al., 2009). We estimate the range of terrestrial carbon cycle-climate sensitivities arising from three climate and four land-cover forcing combinations, then assess the robustness of carbon flux trends. Our discussion focuses on the main features of residual error that arise from bottom-up carbon-budget assessments to better understand process-based interpretations of the airborne fraction.

\section{Data and methods}

\subsection{Forcing data}

Climate forcing data are available globally for either spatially interpolated observations from weather stations or for assimilated observational datasets using reanalysis techniques. For climate observations, we obtained data for precipitation, temperature, cloud cover, and monthly wet days from the Climatic Research Unit (CRU) TS3.0 dataset (Mitchell and Jones, 2005). Two reanalysis datasets were also included: ERA-Interim (Berrisford et al., 2009; Uppala et al., 2005) and the NCEP-DOE Reanalysis II (Kanamitsu et al., 2002). In the case of reanalysis data, short and longwave downward radiation estimates directly replaced cloud cover inputs. The spatial and temporal resolution of the climate forcing data (Table 1) was resampled to a regular-interval $0.5^{\circ}$ latitudelongitude grid using a bilinear interpolation method.

We modified a coupled biogeography-biogeochemistry model, the LPJmL v3.1 DGVM (Sitch et al., 2003), which includes updated hydrology and land-use schemes (Gerten et al., 2004; Bondeau et al., 2007), to assimilate static plant functional type (PFT) distributions. In dynamic vegetation mode, DGVM models only approximately represent present day patterns of natural and managed land-cover fractions, and include considerable uncertainty in the geographic distribution of PFTs. This uncertainty in PFT distributions results from both incomplete bioclimatic information to define the fundamental niche, and to the complexity of modeling species competitive interactions that define the realized niche. To better represent present-day managed and natural land cover, four plant functional type datasets were created using a uniform methodology that combined Köppen-Geiger climate zones (delineated with climate data from the Global Historical Climatological Network v2.0 (Peel et al., 2007)) with physiognomy and phenology-type, and managed or natural grasslands, from land-cover data provided by MODIS (V004 and V005), GLC2000, and GlobCover (Table 2; Poulter et al., 2011). The satellite derived PFT fractions were prescribed directly to the maximum annual FPAR variable in LPJ, which defines the fraction of photosynthetic active radiation (FPAR) absorbed by each PFT and is equal to that PFT's fractional coverage. Maximum annual FPAR was adjusted on a daily time step to reflect changes in temperature or moisture limited phenological status. PFT-specific bioclimatic thresholds (from Sitch et al., 2003) were modified to allow establishment whenever a PFT fraction was present in the prescribed dataset.

Fifteen global simulations were performed, one for each unique climate and diagnostic (i.e. prescribed) land-cover 
Table 2. Remotely sensed land-cover data sets and their corresponding spatial resolution and classification approach (where IGBP is the International Geosphere Biosphere Program, and UN LCCS is the United Nations Land Cover Classification System).

\begin{tabular}{llllll}
\hline Land cover product & Satellite and sensor type & Time period & $\begin{array}{l}\text { Spatial } \\
\text { resolution }\end{array}$ & Number of land cover classes & Reference \\
\hline GLC2000 v1.1 & SPOT-4 (VEGA2000) & 2000 & $1000 \mathrm{~m}$ & 22 (modified UN LCCS) & $\begin{array}{l}\text { Bartholome and } \\
\text { Belward (2005) } \\
\text { Friedl et al. }\end{array}$ \\
Mod12q1 C004 & Terra & 2001 & $1000 \mathrm{~m}$ & 17 (IGBP legend) \\
Mod12q1 C005 & Terra & 2005 & $500 \mathrm{~m}$ & 17 (IGBP legend) & $\begin{array}{l}\text { Friedl et al. } \\
(2010)\end{array}$ \\
GlobCover v2.2 & Envisat (Meris) & Dec 2004/Jun 2006 & $300 \mathrm{~m}$ & 22 (modified UN LCCS) & $\begin{array}{l}\text { Arino et al. } \\
(2008)\end{array}$ \\
\hline
\end{tabular}

combination, as well as a control run with prognostic (fully dynamic) vegetation and the HYDE database representing cropland fractions (Ramankutty and Foley, 1998). A 1000year spin up with natural vegetation (followed by a 398-year spin up for natural and managed lands) to equilibrate soil and vegetation carbon stocks was implemented by applying pre-industrial $\mathrm{CO}_{2}$ concentrations and recycling the first 30 years of climate data for CRU. In the case of ERA-Interim and NCEP-DOE forcing, we applied 20th century CRU climate trends to hind-cast from the reanalysis start year to 1901 so that consistency was maintained between the spin-up and transient simulation; Table 1). Transient simulations, beginning in 1901 and ending in 2005, included $\mathrm{CO}_{2}$ concentrations from CDIAC (Keeling and Whorf, 2005) and soil texture characteristics from FAO (Zobler, 1986). Monthly temperature and precipitation were interpolated to quasi-daily values, while monthly precipitation was randomly distributed to quasi-daily values using a weather generator dependent on number of wet days per month (Geng et al., 1986), or daily climate data were used when available (Table 1). Cloud cover was converted to photosynthetic active radiation (PAR) following Prentice et al. (1993) and transmissivity coefficients of Linacre (1968). Land cover was maintained fixed to the diagnostic input and therefore carbon emissions from net land-cover change were estimated from independent data (Sect. 3.1). Fire dynamics were implemented for natural PFTs but not for croplands, all of which were treated as pasture, with the assumption that grass harvest occurred when LAI reached its maximum annual value (Bondeau et al., 2007). Mortality caused by fire had the effect of reducing the PFT population size and the scaling of productivity and respiration from the individual, but not the fractional abundance of PFTs, which remained fixed to prescribed PFT input.

\subsection{Climate sensitivities and trends in carbon fluxes}

Annual net ecosystem exchange (NEE; Pg C a ${ }^{-1}$ ) was calculated as the difference between carbon inputs from net primary production (NPP) and seedling establishment, and carbon losses from heterotrophic respiration $(\mathrm{RH})$, fire emissions $(\mathrm{F})$ and harvested grass $(\mathrm{H})$. Annual anomalies, from 1989 to 2005, of global NEE and air temperature were calculated with respect to a 10-year baseline period (1996 to 2005). To estimate the sensitivity of NEE to climate, simple linear regression of annual NEE and temperature anomalies obtained in the 15 simulations was performed. The significance of the contemporary (1989-2005) trends in NEE and its component fluxes (NPP and RH) were evaluated using the signal to noise ratio for each $0.5^{\circ}$ grid cell $(n=59199)$. The signal to noise ratio was estimated as the mean of each individual annual carbon flux trend (i.e. for each climate and land cover combination) divided by the standard deviation of the trend for all combinations.

\section{Results and discussion}

\subsection{Comparison of forcing data and carbon fluxes}

Averaged over the 1996 to 2005 period, the global CRU climate data tended to be slightly warmer $\left(13.8^{\circ} \mathrm{C}\right)$, drier $\left(850.9 \mathrm{~mm} \mathrm{a}^{-1}\right)$, and have lower solar radiation $\left(166.9 \mathrm{~W} \mathrm{~m}^{-2}\right)$ than ERA-Interim $\left(13.7^{\circ} \mathrm{C}, 901.4 \mathrm{~mm} \mathrm{a}^{-1}\right.$, $\left.190.3 \mathrm{~W} \mathrm{~m}^{-2}\right)$ and NCEP-DOE $\left(13.1^{\circ} \mathrm{C}, 930.6 \mathrm{~mm} \mathrm{a}^{-1}\right.$, $195.6 \mathrm{~W} \mathrm{~m}^{-2}$ ). Differences in incoming solar radiation can be partly explained by the use of atmospheric transmissivity constants (Linacre, 1968) used to convert CRU cloud cover to shortwave radiation, however previous studies have confirmed a systematic positive bias to be common in both reanalysis datasets (Hicke, 2005; Zhang et al., 2007). At the regional scale, NCEP-DOE had higher summertime precipitation for all mid-latitude regions (Europe, South and North America) as well as in tropical Asia, but NCEP-DOE tended to be drier in tropical South America (Fig. 1). CRU was noticeably warmer over tropical South America $\left(1-1.5^{\circ} \mathrm{C}\right)$ and NCEP was approximately $1^{\circ} \mathrm{C}$ cooler over North Africa and Tropical Asia. The plant functional type datasets diverged from one another mainly over dry-regions because of 
Table 3. Summary of mean annual carbon fluxes for each of the 15 global simulations, averaged over the period 1996-2005.

\begin{tabular}{|c|c|c|c|c|c|}
\hline \multirow{2}{*}{ Climate forcing } & \multirow{2}{*}{ Land cover forcing } & \multirow{2}{*}{ Cropland \& pasture area $\left(\mathrm{km}^{2}\right)$} & \multicolumn{3}{|c|}{ C- fluxes $\left(\mathrm{Pg} \mathrm{C} \mathrm{a}^{-1}\right)$} \\
\hline & & & NPP & $\mathrm{RH}$ & NEE \\
\hline \multirow{5}{*}{ CRU TS3.0 } & Hyde/dynamic & $3.2(21.9 \%)$ & 56.97 & 48.81 & -1.68 \\
\hline & GLC2000 & $1.8(12.4 \%)$ & 57.97 & 47.49 & -1.91 \\
\hline & GlobCover & 1.7 (11.7) & 56.19 & 46.46 & -1.72 \\
\hline & Modis V4 & $1.3(9.2 \%)$ & 55.73 & 47.59 & -1.55 \\
\hline & Modis V5 & $1.3(9.2 \%)$ & 56.89 & 48.59 & -1.66 \\
\hline \multirow{5}{*}{ ERA-Interim } & Hyde/dynamic & \multirow{10}{*}{ (as above) } & 54.1 & 47.31 & -1.75 \\
\hline & GLC2000 & & 54.6 & 45.37 & -1.99 \\
\hline & GlobCover & & 53.2 & 44.29 & -1.89 \\
\hline & Modis V4 & & 52.43 & 44.83 & -2.04 \\
\hline & Modis V5 & & 53.46 & 45.78 & -2.14 \\
\hline \multirow{5}{*}{ NCEP-DOE II } & Hyde/dynamic & & 60.17 & 54.8 & 1.08 \\
\hline & GLC2000 & & 60.1 & 50.64 & -1.03 \\
\hline & GlobCover & & 58.62 & 49.57 & -1.08 \\
\hline & Modis V4 & & 58 & 50.07 & -1.18 \\
\hline & Modis V5 & & 59.27 & 51.29 & -1.28 \\
\hline
\end{tabular}

Table 4. Sensitivity (slope of linear regression) of the uncertainty of net ecosystem exchange, expressed as coefficient of variation (CV), to the uncertainty of net primary production and heterotrophic respiration component fluxes (CV). The analysis was conducted on area aggregated fluxes that corresponded TransCom3 regions (Fig. 1). The uncertainty of NEE in northern regions is mainly controlled by RH uncertainty (implying greater temperature sensitivity of soil respiration), whereas in topical and arid regions, NPP and RH uncertainty are equally important.

\begin{tabular}{lcc}
\hline $\begin{array}{l}\text { Region (ordered from cool/dry } \\
\text { to wet to warm/dry) }\end{array}$ & $\begin{array}{c}\text { Slope of NEE CV to component } \\
\text { flux CV (\%) }\end{array}$ \\
\cline { 2 - 3 } & NPP & RH \\
\hline Boreal North America & 0.094 & 0.137 \\
Boreal Russia & 0.053 & 0.131 \\
Europe & 0.012 & 0.123 \\
Temperate North America & 0.12 & 0.163 \\
Temperate Asia & 0.055 & 0.052 \\
South Africa & 0.05 & 0.061 \\
Tropical Asia & -0.005 & -0.01 \\
Tropical South America & 0.067 & 0.138 \\
South America & 0.02 & 0.047 \\
North Africa & 0.012 & 0.015 \\
Australia & 0.085 & 0.092 \\
\hline
\end{tabular}

differences in how the classification systems handled forest cover thresholds (Poulter et al., 2011; Fritz and See, 2008). Due to these classification differences, the GLC2000 and GlobCover datasets tended to have 4-5\% higher woody vegetation in warm regions, which MODIS categorized as $\mathrm{C} 4$ grasslands.
The carbon flux estimates (Table 3 ) were within the range of previous studies using independent methods from remote sensing (Zhao and Running, 2010) and also comparable to other DGVM models (Sitch et al., 2008) and global atmospheric inversions (Gurney et al., 2002). Variation in the magnitude of carbon fluxes was mainly related to climate forcing uncertainty, with global NPP (for the averaging period 1996-2005) ranging from 52.4 to $60.2 \mathrm{Pg} \mathrm{C} \mathrm{a}^{-1}$ (a $13 \%$ range) and $\mathrm{RH}$ from 44.3 to $54.8 \mathrm{Pg} \mathrm{C} \mathrm{a}^{-1}(19 \%)$. Because soil respiration is tightly coupled to aboveground production and carbon inputs, RH tended to respond proportionally with NPP, resulting in a smaller range of absolute NEE variability -1.08 to $-2.14 \mathrm{Pg} \mathrm{C} \mathrm{a}^{-1}$, but representing $\sim 50 \%$ uncertainty. The uncertainty of NEE was especially large in tropical South America, Central Africa and in Eastern Europe (Fig. 2). These hotspots of uncertainty either have large absolute fluxes that lead to large uncertainty (i.e. the tropics), and/or occur where differences in climate and landcover forcing caused a disproportionately larger uncertainty for RH fluxes rather than NPP (i.e. in central Europe, Table 4). The temporal dynamics and inter-annual variability of global NEE showed strong coherence among climate forcing (Fig. 3a), but large systematic biases emerged from climate, and less so, for land-cover forcing datasets.

We estimated the inferred terrestrial carbon sink (ICS) from carbon cycle observations, where, ICS $=$ (fossil fuel + net land use) - atmospheric sink - ocean sink (using sink/source data from Le Quere et al. (2009), http: //lgmacweb.env.uea.ac.uk/lequere/co2/carbon_budget.htm; accessed January 2011), In comparison to the ICS, the LPJ simulated terrestrial carbon sink followed similar 

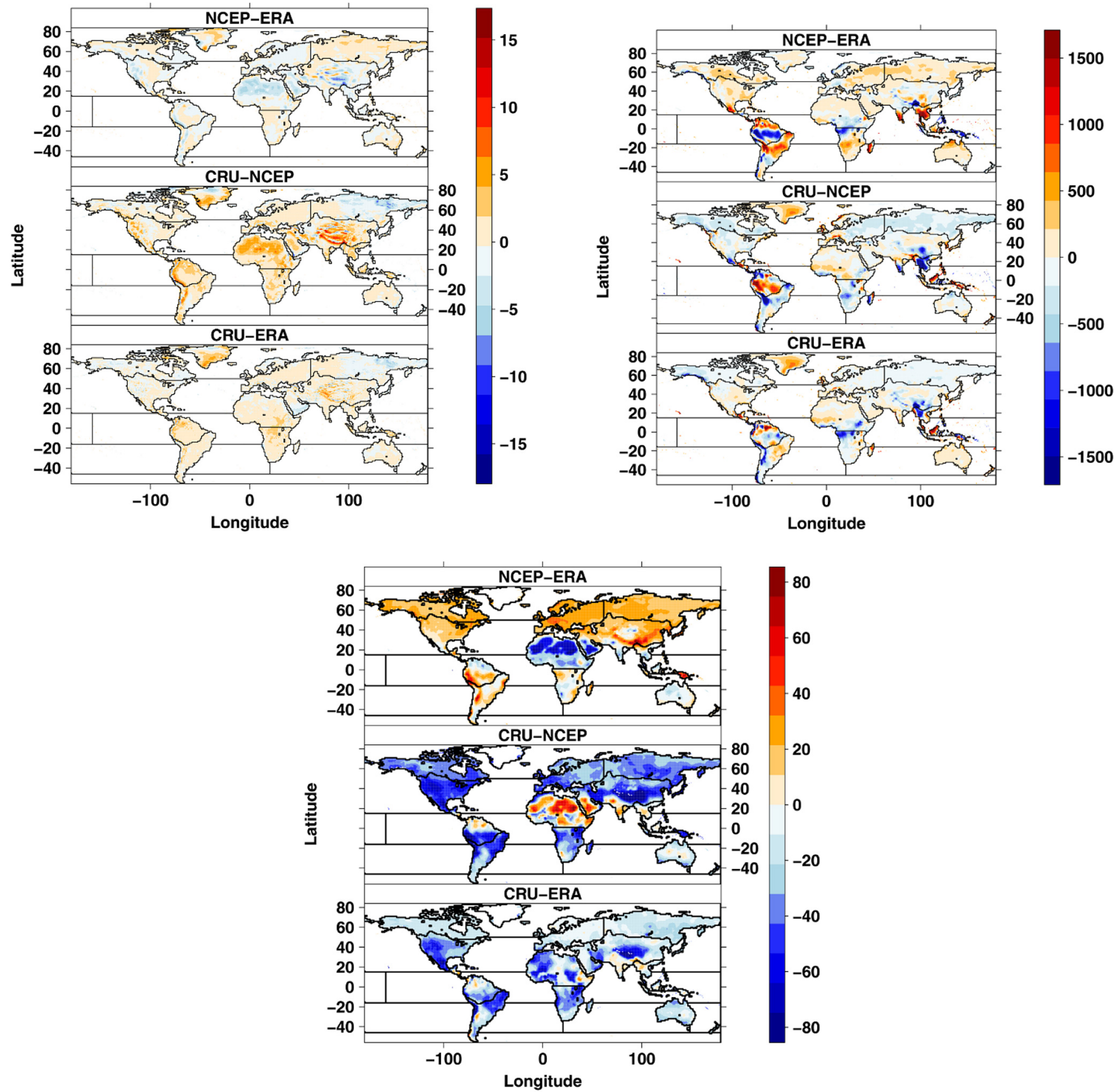

Fig. 1. (a) Spatial pattern of climate forcing differences between mean annual temperature, (b) total annual precipitation, and (c) downward shortwave radiation.

inter-annual variability and decadal trends, but was unable to reproduce a strong 1991/92 anomaly following the Mt. Pinatubo eruption (Fig. 3a). The Pinatubo eruption was associated with cooler temperatures and increased diffuse solar radiation (Mercado et al., 2009; Peylin et al., 2005), resulting in an enhanced effect on photosynthesis that is not explicitly considered in LPJ.

\subsection{Carbon-climate sensitivities and temporal trends}

The range of carbon flux sensitivity of to climate forcing provides a useful indicator for interpreting the magnitude of component and net flux inter-annual variability. Overall, we found that climate forcing explained most of the variation between carbon-climate sensitivities, via its role on enhancing or alleviating abiotic limitations, and that land cover had a minor secondary role (Table 5). At the global scale, 


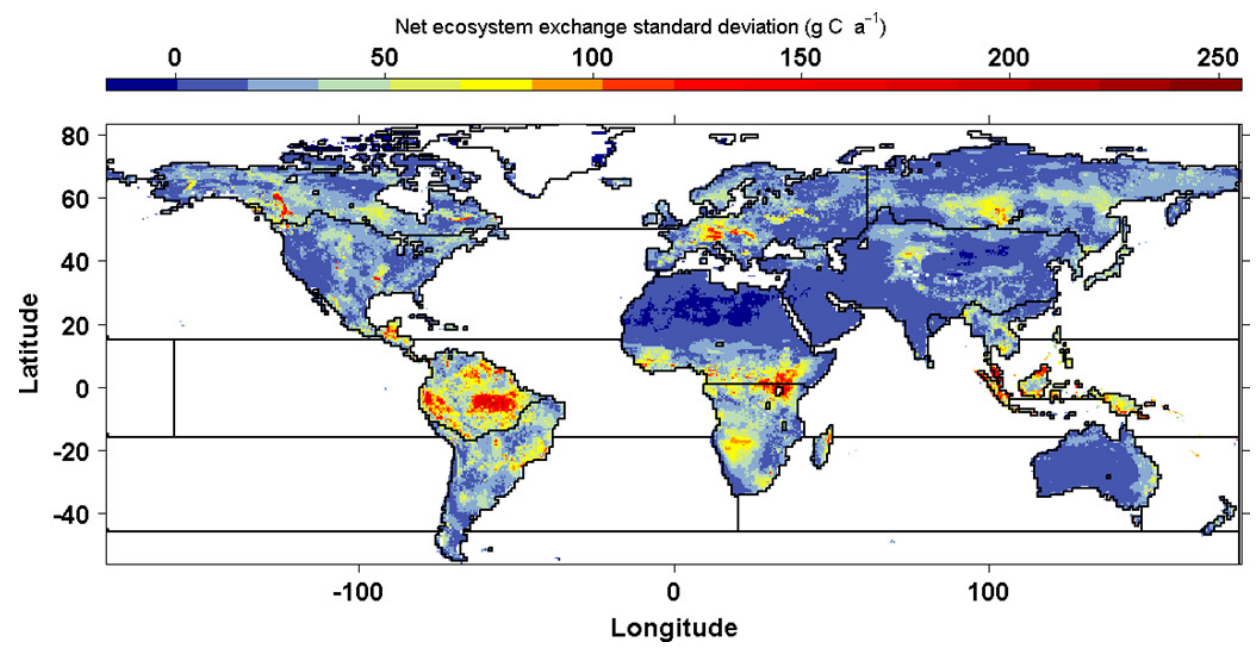

Fig. 2. Standard deviation of annual net ecosystem exchange $\left(\mathrm{g} \mathrm{C} \mathrm{m}^{-2} \mathrm{a}^{-1}\right)$ calculated from the 3 climate $\times 5$ land cover forcing simulations. Borders represent TransCom 3 regions (Gurney et al., 2002) that correspond to biogeographic zones used in the analysis for Table 5.
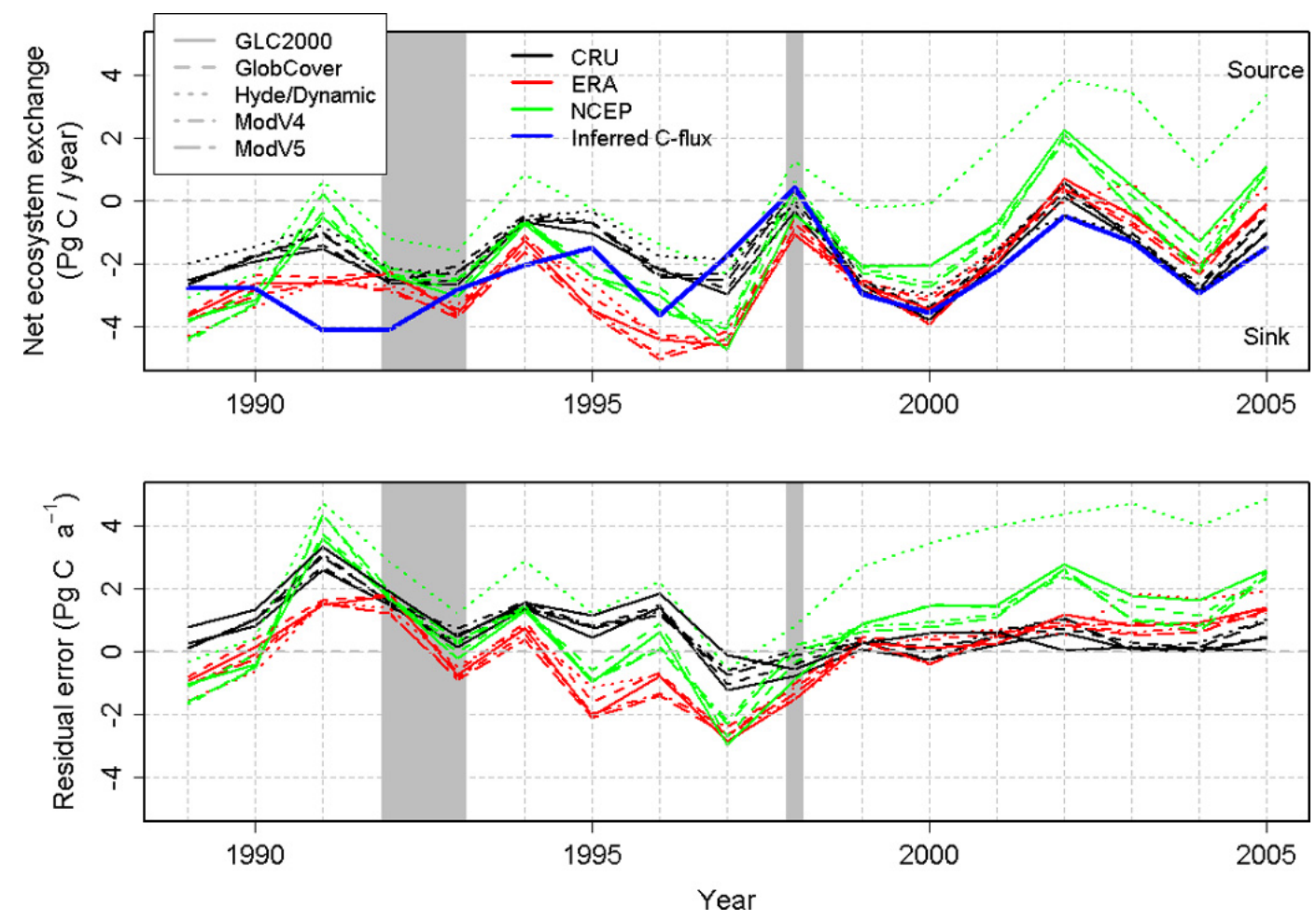

Fig. 3. (a) Temporal dynamics of net ecosystem exchange for the common overlapping time period of CRU, ERA-Interim, and NCEP-DOE (Table 1), and (b) the residual error from accounting method to assess global carbon sources and sinks (Sect. 3.1). The Mt. Pinatubo eruption and El Niño Southern Oscillation event of 1997/98 are both highlighted.

NCEP-DOE had the largest NEE sensitivity to changes in temperature (4.2-5.9 $\mathrm{Pg} \mathrm{C} \mathrm{K}^{-1}$ ), followed by ERA-Interim (4.1-4.5 $\mathrm{Pg} \mathrm{C} \mathrm{K}^{-1}$ ) and then CRU (1.2-2.5 $\left.\mathrm{Pg} \mathrm{C} \mathrm{K}^{-1}\right)$. These differences were largely explained by tropical ecosystem dynamics, where productivity reacted strongly to variation in temperature in the absence of temperature stress and water limitations (i.e. where NCEP-DOE tended to be cooler in the tropics, Fig. 1). In temperate regions, the ERA-Interim climate forcing caused higher NEE sensitivity to temperature mainly because of higher heterotrophic respiration sensitivity to changes in air temperature (Table 5). Terrestrial NEE inferred from observations (the ICS, Sect. 3.1) exhibited lower 
Table 5. Sensitivity of global annual net ecosystem exchange fluxes (NEE) to temperature anomalies for 1989-2005 ( $p<0.1$ for all land cover and climate forcing combinations, except for the dynamic vegetation and CRU combination $=0.15$ ).

\begin{tabular}{lccc}
\hline \multirow{2}{*}{ Land cover forcing } & \multicolumn{3}{c}{ Climate forcing and carbon-climate sensitivity $\left(\mathrm{Pg} \mathrm{C} \mathrm{K}^{-1}\right)$} \\
\cline { 2 - 4 } & CRU TS 3.0 & ERA-Interim & NCEP-DOE II \\
\hline Hyde/dynamic & $1.25 \pm 0.82$ & $4.45 \pm 1.09$ & $5.99 \pm 1.36$ \\
GLC2000 & $2.02 \pm 0.91$ & $3.65 \pm 1.14$ & $4.50 \pm 1.37$ \\
GlobCover & $2.26 \pm 0.89$ & $3.58 \pm 1.05$ & $4.19 \pm 1.27$ \\
MODIS V004 & $2.54 \pm 0.95$ & $4.18 \pm 1.06$ & $4.53 \pm 1.40$ \\
MODIS V005 & $2.53 \pm 0.97$ & $4.07 \pm 1.07$ & $4.23 \pm 1.46$ \\
Observations (inferred terrestrial carbon sink) & $1.92 \pm 0.87$ & $1.90 \pm 0.84$ & $1.78 \pm 0.97$ \\
\hline
\end{tabular}

carbon-climate sensitivity (1.7-1.9 Pg C K $\mathrm{K}^{-1}$ ), and was more closely aligned to the simulated carbon-climate sensitivities from the CRU forcing.

Overall, the estimated global carbon cycle temperature sensitivities presented here are substantially lower than best estimates for carbon-cycle climate sensitivities quantified for multi-decadal to centennial time-scales during the preindustrial past millennium (Frank et al., 2010). Our comparison among forcing scenarios clearly demonstrates how even small biases in absolute temperature and/or precipitation in coupled carbon-cycle climate simulations can contribute to a wide spread and possible overestimation of the strength of carbon cycle feedbacks (Friedlingstein et al., 2003). Compared to the sensitivity of the inferred terrestrial carbon sink, it thus appears particularly important to have unbiased estimates of climate when trying to diagnose vegetation coupling in earth system simulations.

Among land-cover forcing datasets, the MODIS land cover was more sensitive to temperature variability (Table 5), possibly because the more extensive, shallow-rooted grasslands had less access to water in the deeper soil layer $(>0.5 \mathrm{~m}$ depth). The prognostic vegetation simulations with dynamic PFT fractions showed a lower NEE sensitivity to temperature using CRU than with ERA-Interim and NCEP-DOE. With dynamic vegetation, physiological processes can be expected to be closer to a climatic equilibrium than the fixed PFT fractions, which were at less-than optimal climate conditions. However, because ERA-Interim and NCEP-DOE forcing were both slightly cooler and wetter, the dynamic vegetation sensitivities were larger, because they were not constrained by high-temperature or low-moisture limitation.

Robust trends of increasing NPP and RH were observed at higher latitudes (Boreal North America and Boreal Russia) for most climate and land-cover forcing datasets, with signal to noise ratios $>2$ (Fig. 4). These findings support previous work showing the effects of increased growing season and $\mathrm{CO}_{2}$ fertilization on the productivity of circumpolar vegetation (Piao et al., 2007). Decreasing NPP was observed in dryland regions, including Australia and parts of South America, as well as in semi-humid areas of South-

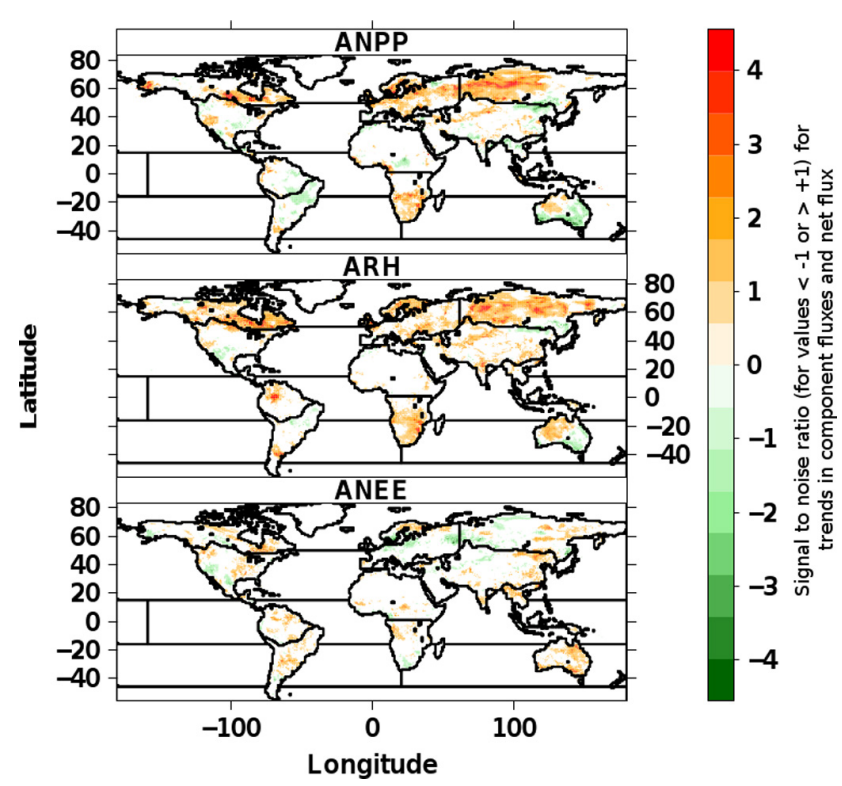

Fig. 4. Signal to noise ratio (for values $<-1$ or $>+1$ ) for annual net primary production (ANPP), heterotrophic respiration (RH), and net ecosystem exchange (NEE). A positive value for NPP and RH indicate increasing rates and a positive value for NEE indicates a trend toward a carbon source.

east Asia. In these regions, $\mathrm{RH}$ did not show as large a decrease as compared to NPP, possibly because of increasing air temperatures, meaning that NEE trended toward a stronger carbon source (Fig. 4). Our results on declining dryland NPP correspond to recent independent studies using remote sensing based models (Zhao and Running, 2010), empirical upscaling (Jung et al., 2010), and field observations (Allen et al., 2010) that suggest soil moisture limitations are increasing in the past decade. At the global scale, decreases in NPP, not offset by a similar decrease in RH, explained the general global trend toward a weakening terrestrial carbon sink (Fig. 3a). This trend was observed for all climate-land cover combinations, and appeared increasingly important from 1998 onward. 


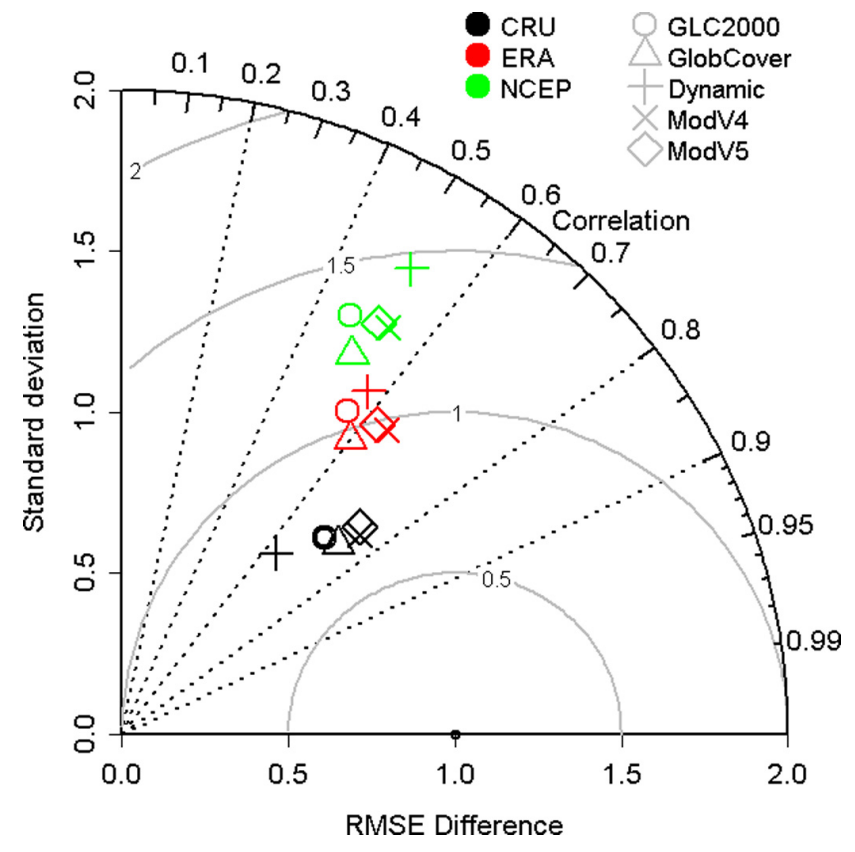

Fig. 5. Taylor diagram assessing model skill in comparison to the inferred terrestrial carbon sink. The black circle located at $\mathrm{RMSE}=1.0$ and Standard Deviation $=0$ indicates the observations.

\subsection{Contribution to reducing the uncertainty of air- borne fraction dynamics}

The summing of global carbon sinks and sources using independent observations results in a residual error if the budget is not closed (Sect. 3.1; Fig. 3b). This residual error and its inter-annual dynamics can be considered an indicator for further constraining and identifying the main component sources of error (i.e. atmosphere, ocean, land sinks and sources). We investigated the year-to-year variability as well as a long-term trend of the residual error and observed a series of positive anomalies beginning in 1998. These positive anomalies modified the long-term trend from 0.03 (1989$2005)$ to $0.23 \mathrm{Pg} \mathrm{C} \mathrm{a}^{-1}$ (1998-2005). The recent trend toward increasing residual error suggests that either weakening terrestrial NPP is too sensitive to recent climate trends, or that another sink/source term in the global carbon budget is poorly constrained. For example, carbon fluxes from net land-use change have high uncertainty (mean $1.5 \pm 0.7 \mathrm{Pg} \mathrm{C}$ $\left.\mathrm{a}^{-1}\right)$ in comparison to ocean fluxes $\left(2.3 \pm 0.5 \mathrm{Pg} \mathrm{C} \mathrm{a}^{-1}\right)$ and the residual trend suggests that downward revisions for deforestation for the 2000-2005 period, using revised land-use change data (Friedlingstein et al., 2010; Houghton, 1999), may be continue to be too small (Grainger, 2008). These results agree with Knorr (2009), who found that the uncertainty of net land-use emissions may be the most a critical component flux in determining the long-term dynamics of the airborne fraction.

\subsection{Evaluation of forcing data and agreement with inferred terrestrial carbon sink}

We compared the time series (1989 to 2005) of all NEE climate and land cover simulations to the inferred carbon sink using a Taylor diagram (Taylor, 2001) to assess multiple metrics of model-data agreement and skill (Fig. 5). The CRU dataset had consistently higher agreement with the inferred terrestrial carbon dynamics $\left(R^{2}=0.7-0.8\right)$, with the MODIS-derived PFT datasets performing slightly better than the GLC2000 and GlobCover. ERA-Interim and NCEP-DOE matched the ICS less well $\left(R^{2}=0.45-0.65\right)$, and resulted in a larger inter-annual amplitude (compared to the ICS) because of the higher NEE-temperature sensitivity (represented by the large standard deviation on the y-axis of Fig. 5).

\section{Conclusions}

Our study demonstrates that the choice of forcing data has significant consequences for interpreting trends and variability of the residual carbon sink, with implications for interpreting the dynamics of the airborne fraction. We conclude that (1) trends in global sinks and sources are robust in Northern latitudes and dry regions, (2) inter-annual variations within these regions can be significant and occur on at least inter-annual to decadal time scales, and (3) reducing uncertainty from net land-use fluxes will be necessary for reducing residual error of the global carbon budget. Le Quere et al. (2009) recommend that the residual error from bottom-up accounting procedures must be reduced to less than $0.9 \mathrm{Pg} \mathrm{C} \mathrm{a}^{-1}$, corresponding to the uncertainty in the fossil fuel emissions, to make process-based model interpretations of the airborne fraction policy-relevant. We show here that the residual error due to land-cover and climate forcing uncertainty is $3.1 \mathrm{Pg} \mathrm{C} \mathrm{a}^{-1}$, which is larger than the model structural uncertainties presented by Le Quere et al. (2009). Land cover contributes approximately $1.1 \mathrm{Pg} \mathrm{C} \mathrm{a}^{-1}$ and climate $1.7 \mathrm{Pg} \mathrm{C} \mathrm{a}^{-1}$ to this overall uncertainty. Consideration of forcing data is required to reduce uncertainty in the interpretation of future trends in the airborne fraction.

Acknowledgements. BP acknowledges funding from an FP7 Marie Curie Incoming International Fellowship (Grant Number 220546). DCF acknowledges support from the EC (Carbo-Extremes) and the Swiss National Science Foundation (NCCR-Climate). ELH and NEZ acknowledge support from the Swiss Competence Center Environment and Sustainability (MAIOLICA). We thank the Potsdam Institute for Climate Impact Research (PIK) for providing LPJ code, and the providers of the climate and land cover forcing datasets, including NCEP, ECMWF, CRU, CDIAC, Boston University, European Commission Joint Research Center and the European Space Agency. We thank Matthias Forkel for his Interactive Comments, and the comments from two anonymous reviewers.

Edited by: V. Brovkin 


\section{References}

Allen, C. D., Macalady, A. K., Chenchouni, H., Bachelet, D., McDowell, N., Vennetier, M., Kitzberger, T., Rigling, A., Breshears, D. D., Hogg, E. H., Gonzalez, P., Fensham, R., Zhang, Z., Castro, J., Demidova, N., Lim, J. H., Allard, G., Running, S. W., Semerci, A., and Cobb, N.: A global overview of drought and heatinduced tree mortality reveals emerging climate change risks for forests, Forest Ecology and Management, 259, 660-684, 2010.

Arino, O., Bicheron, P., Achard, F., Latham, J., Witt, R., and Weber, J. L.: GLOBCOVER The most detailed portrait of Earth, ESA Bulletin-European Space Agency, 136, 24-31, 2008.

Bartholome, E. and Belward, A. S.: GLC2000: a new approach to global land cover mapping from Earth observation data, Int. J. Remote Sens., 26, 1959-1977, 2005.

Berrisford, P., Dee, D. K., Fuentes, M., Kallberg, P., Kobayashi, S., and Uppala, S.: The ERA-Interim archive. ERA-40 Report Series No. 1, ECMWF, Shinfield Park, Reading, 2009.

Bondeau, A., Smith, P. C., Zaehle, S., Schaphoff, S., Lucht, W., Cramer, W., Gerten, D., Lotze-Campen, H., Müller, C., Reichstein, M., and Smith, B.: Modelling the role of agriculture for the 20th century global carbon balance, Global Change Biol., 13, 679-706, 2007.

Frank, D., Esper, J., Raible, C. C., Buntgen, U., Trouet, V., Stocker, B., and Joos, F.: Ensemble reconstruction constraints on the global carbon cycle sensitivity to climate, Nature, 463, 527-530, 2010.

Friedl, M. A., McIver, D. K., Hodges, J. C. F., Zhang, X. Y., Muchoney, D., Strahler, A. H., Woodcock, C. E., Gopal, S., Schneider, A., Cooper, A., Baccini, A., Gao, F., and Schaaf, C. B.: Global Land Cover Mapping from MODIS: Algorithms and Early Results, Remote Sens. Environ., 83, 287-302, 2002.

Friedl, M., Sulla-Menashe, D., Tan, B., Schneider, A., Ramankutty, N., Sibley, A., and Huang, X.: MODIS Collection 5 Global Land Cover: Algorithm refinements and characterization of new datasets, Remote Sens. Environ., 114, 168-182, 2010.

Friedlingstein, P., Dufresne, J. L., Cox, P. M., and Rayner, P.: How positive is the feedback between climate change and the carbon cycle?, Tellus, 55B, 692-700, 2003.

Friedlingstein, P., Houghton, R. A., Marland, G., Hackler, J., Boden, T. A., Conway, T. J., Canadell, J. G., Raupach, M. R., Ciais, P., and Le Quere, C.: Update on $\mathrm{CO}_{2}$ emissions, Nature Geosci., 3, 811-812, 2010.

Fritz, S. and See, L.: Identifying and quantifying uncertainty and spatial disagreement in the comparison of Global Land Cover for different applications, Global Change Biol., 14, 1057-1075, 2008.

Geng, S., Penning de Vries, F. W. T., and Supit, I.: A simple method for generating daily rainfall data, Agric. Forest Meteor., 36, 363376, 1986.

Gerten, D., Schaphoff, S., Haberlandt, U., Lucht, W., and Sitch, S.: Terrestrial vegetation and water balance - hydrological evaluation of a dynamic global vegetation model, J. Hydrol., 286, 249-270, 2004.

Grainger, A.: Difficulties in tracking the long-term global trend in tropical forest area, Proceedings of the National Academy of Science, 105, 818-823, 2008.

Gurney, K. R., Law, R. M., Denning, A. S., Rayner, P., Baker, D., Bousquet, P., Bruhwiler, L., Chen, Y. H., Ciais, P., Fan, S. M., Fung, I. Y., Gloor, M., Heimann, M., Higuchi, N., John, J., Maki,
T., Maksyutov, S., Masarie, K., Peylin, P., Prather, M., Pak, B. C., Randerson, J. T., Sarmiento, J., Taguchi, S., Takahashi, T., and Yuen, C. W.: Towards robust regional estimates of $\mathrm{CO}_{2}$ sources and sinks using atmospheric transport models, Nature, 415, 626630, 2002.

Hicke, J. A.: NCEP and GISS solar radiation data sets available for ecosystem modeling: Description, differences, and impacts on net primary production, Global Biogeochem. Cycles, 19, GB2006, doi:10.1029/2004GB002391, 2005.

Houghton, R. A.: The annual net flux of carbon to the atmosphere from changes in land use 1850-1990, Tellus, 51B, 298-313, 1999.

Huntingford, C., Lowe, J., Booth, B. B. B., Jones, C. D., and Harris, G. R.: Contributions of carbon cycle uncertainty to future climate projection spread, Tellus, 61B, 355-360, 2009.

Jung, M., Vetter, M., Herold, M., Churkina, G., Reichstein, M., Zaehle, S., Ciais, P., Viovy, N., Bondeau, A., Chen, Y., Trusilova, K., Feser, F., and Heimann, M.: Uncertainties of modeling gross primary productivity over Europe: A systematic study on the effects of using different drivers and terrestrial biosphere models, Global Biogeochem. Cycles, 21, GB4021, doi:10.1029/2006GB002915, 2007.

Jung, M., Reichstein, M., Ciais, P., Seneviratne, S. I., Sheffield, J., Goulden, M. L., Bonan, G., Cescatti, A., Chen, J. Q., de Jeu, R., Dolman, A. J., Eugster, W., Gerten, D., Gianelle, D., Gobron, N., Heinke, J., Kimball, J., Law, B. E., Montagnani, L., Mu, Q. Z., Mueller, B., Oleson, K., Papale, D., Richardson, A. D., Roupsard, O., Running, S., Tomelleri, E., Viovy, N., Weber, U., Williams, C., Wood, E., Zaehle, S., and Zhang, K.: Recent decline in the global land evapotranspiration trend due to limited moisture supply, Nature, 467, 951-954, 2010.

Kalnay, E., Kanamitsu, M., Kistler, R., Collins, W., Deaven, D., Gandin, L., Iredell, M., Saha, S., White, G., Woollen, J., Zhu, Y., Chelliah, M., Ebisuzaki, W., Higgins, W., Janowiak, J., Mo, K. C., Ropelewski, C., Wang, J., Leetmaa, A., Reynolds, R., Jenne, R., and Joseph, D.: The NCEP/NCAR 40-year reanalysis project, B. Am. Meteorol. Soc., 77, 437-471, 1996.

Kanamitsu, M., Ebisuzaki, W., Woollen, J., Yang, S. K., Hnilo, J. J., Fiorino, M., and Potter, G. L.: NCEP-DEO AMIP-II Reanalysis (R-2), B. Am. Meteorol. Soc., 83, 1631-1643, 2002.

Keeling, C. D. and Whorf, T.: Atmospheric $\mathrm{CO}_{2}$ records from sites in the SIO air sampling network, Carbon Dioxide Information Analysis Center, Oak Ridge National Laboratory, Oak Ridge Tenn., 2005.

Knorr, W.: Is the airborne fraction of anthropogenic $\mathrm{CO}_{2}$ emissions increasing?, Geophys. Res. Lett., 36, L21710, doi:10.1029/2009GL040613, 2009.

Le Quere, C., Raupach, M., Canadell, J., Marland, G., Bopp, L., Ciais, P., Conway, T., Doney, S., Feely, R., Foster, P., Friedlingstein, P., Gurney, K., Houghton, R., House, J., Huntingford, C., Levy, P., Lomas, M., Majkut, J., Metzl, N., Ometto, J., Peters, G., Prentice, I., Randerson, J., Running, S., Sarmiento, J., Schuster, U., Sitch, S., Takahashi, T., Viovy, N., and van der Werf, G.: Trends in the sources and sinks of carbon dioxide, Nature Geosci., 2, 831-836, 2009.

Linacre, E. T.: Estimating the net-radiation flux, Agricultural meteorology, 5, 49-63, 1968.

McGuire, A. D., Sitch, S., Clein, J. S., Dargaville, R., Esser, G., Foley, J. A., Heimann, M., Joos, F., Kaplan, J. O., Kicklighter, 
D. W., Meier, R. A., Melillo, J. M., Moore III, B., Prentice, I. C., Ramankutty, N., Reichenau, T., Schloss, A., Tian, H., Williams, L. J., and Wittenberg, U.: Carbon balance of the terrestrial biosphere in the twentieth century: Analyses of CO, climate and land use effects with four process-basede cosystemm odels, Global Biogeochem. Cycles, 15, 183-206, 2001.

Meinshausen, M., Meinshausen, N., Hare, W., Raper, S. C. B., Frieler, K., Knutti, R., Frame, D. J., and Allen, M. R.: Greenhouse-gas emission targets for limiting global warming to 2C, Nature, 458, 1158-1163, 2009.

Mercado, L., Bellouin, N., Sitch, S., Boucher, O., Huntingford, C., Wild, M., and Cox, P. M.: Impact of changes in diffuse radiation on the global land carbon sink, Nature, 458, 1014-1087, 2009.

Mitchell, C. D. and Jones, P.: An improved method of constructing a database of monthly climate observations and associated highresolution grids, Int. J. Climatol., 25, 693-712, 2005.

Ostle, N. J., Smith, P., Fisher, R. A., Woodward, F. I., Fisher, J. B., Smith, J. U., Galbraith, D., Levy, P. E., Meir, P., McNamara, N. P., and Bardgett, R. D.: Integrating plant-soil interactions into global carbon cycle models, J. Ecology, 97, 851-863, 2009.

Peel, M. C., Finlayson, B. L., and McMahon, T. A.: Updated world map of the Köppen-Geiger climate classification, Hydrol. Earth Syst. Sci., 11, 1633-1644, doi:10.5194/hess-11-16332007, 2007.

Peylin, P., Bousquet, P., Le Quere, C., Sitch, S., Friedlingstein, P., McKinley, G., Gruber, N., Rayner, P., and Ciais, P.: Multiple constraints on regional $\mathrm{CO}_{2}$ flux variations over land and oceans, Global Biogeochem. Cycles, 19, GB1101, doi:10.1029/2003GB002214, 2005.

Piao, S., Friedlingstein, P., Ciais, P., Viovy, N., and Demarty, J.: Growing season extension and its impact on terrestrial carbon cycle in the Northern Hemisphere over the past 23 decades, Global Biogeochem. Cycles, 21, GB3018, doi:10.1029/2006GB002888, 2007.

Poulter, B., Ciais, P., Hodson, E. L., Lischke, H., Maignan, F., Plummer, S., and Zimmermann, N. E.: Plant functional type mapping for earth system models, Geosci. Model Dev. Discuss., submitted, 2011.

Prentice, I. C., Sykes, M. T., and Cramer, W.: A simulation model for the transient effects of climate change on forest landscapes, Ecological Modelling, 65, 51-70, 1993.

Quaife, T., Quegan, S., Disney, M., Lewis, P., Lomas, M. R., and Woodward, F. I.: Impact of land cover uncertainties on estimates of biospheric carbon fluxes, Global Biogeochem. Cycles, 22, GB4016, doi:10.1029/2007GB003097, 2008.

Ramankutty, N. and Foley, J. A.: Characterizing patterns of global land use: An analysis of global croplands data, Global Biogeochem. Cycles, 12, 667-685, 1998.

Sarmiento, J. L., Gloor, M., Gruber, N., Beaulieu, C., Jacobson, A. R., Mikaloff Fletcher, S. E., Pacala, S., and Rodgers, K.: Trends and regional distributions of land and ocean carbon sinks, Biogeosciences, 7, 2351-2367, doi:10.5194/bg-7-2351-2010, 2010.
Sitch, S., Smith, B., Prentice, I. C., Arneth, A., Bondeau, A., Cramer, W., Kaplan, J. O., Levis, S., Lucht, W., Sykes, M. T., Thonicke, K., and Venevsky, S.: Evaluation of ecosystem dynamics, plant geography and terrestrial carbon cycling in the LPJ dynamic global vegetation model, Global Change Biology, 9, 161-185, 2003.

Sitch, S., Huntingford, C., Gedney, N., Levy, P. E., Lomas, M. R., Piao, S., Betts, R. A., Ciais, P., Cox, P. M., Friedlingstein, P., Jones, C. D., Prentice, I. C., and Woodward, F. I.: Evaluation of the terrestrial carbon cycle, future plant geography and climate-carbon cycle feedbacks using five Dynamic Global Vegetation Models (DGVMs), Global Change Biology, 14, 20152039, 2008.

Taylor, K. E.: Summarizing multiple aspects of model performance in a single diagram, J. Geophys. Res., 106, 7183-7192, 2001.

Uppala, S. M., Kallberg, P., Simmons, A., Andrae, U., Bechtold, V. D., Fiorino, M., Gibson, J. K., Haseler, J., Hernandez, A., Kelly, G. A., Li, X., Onogi, K., Saarinen, S., Sokka, N., Allan, R. P., Andersson, E., Arpe, K., Balmaseda, M. A., Beljaars, A. C. M., Van De Berg, L., Bidlot, J., Bormann, N., Caires, S., Chevallier, F., Dethof, A., Dragosavac, M., Fisher, M., Fuentes, M., Hagemann, S., Holm, E., Hoskins, B. J., Isaksen, L., Janssen, P. A. E. M., Jenne, R., McNally, A. P., Mahfouf, J. F., Morcrette, J. J., Rayner, N. A., Saunders, R. W., Simon, P., Sterl, A., Trenberth, K. E., Untch, A., Vasiljevic, D., Viterbo, P., and Woollen, J.: The ERA-40 re-analysis, Q. J. Roy. Meteorol. Soc., 131, 2961-3012, 2005.

Zaehle, S., Sitch, S., Smith, B., and Hattermann, F.: Effects of parameter uncertainty on the modeling of terrestrial biosphere dynamics, Global Biogeochem. Cycles, 19, GB3020, doi:3010.1029/2004GB002395, 2005.

Zhang, K., Kimball, J., Zhao, M., Oechel, W. C., Cassano, J., and Running, S. W.: Sensitivity of pan-Arctic terrestrial net primary productivity simulations to daily surface meteorology from NCEP-NCAR and ERA-40 reanalyses, J. Geophys. Res., 112, G01011, doi:10.1029/2006JG000249, 2007.

Zhao, M. and Running, S. W.: Drought-Induced Reduction in Global Terrestrial Net Primary Production from 2000 Through 2009, Science, 329, 940-943, 2010.

Zhao, M., Running, S. W., and Nemani, R.: Sensitivity of Moderate Resolution Imaging Spectroradiometer (MODIS) terrestrial primary production to the accuracy of meteorological reanalyses, J. Geophys. Res., 111, G01002, doi:10.1029/2004JG000004, 2006.

Zobler, L.: A world soil file for global climate modeling, NASA Technical Memorandum, 32 pp, 1986. 